\title{
Pengaruh Media Pembelajaran terhadap Motivasi Belajar: Tinjauan berdasarkan Karakter Generasi Z
}

\author{
M. Ichsan Nawawi \\ Jurusan Matematika, Fakultas Sains dan Teknologi, UIN Alauddin Makassar, Jl. H.M. Yasin Limpo, \\ Romangpolong, Gowa, 92113, Indonesia \\ *Corresponding Author e-mail: ichsan.nawawi@uin-alauddin.ac.id \\ Received: June 2020; Revised: June 2020; Published: July 2020
}

\begin{abstract}
Abstrak
Salah satu permasalahan yang menarik adalah perbedaan karakter mahasiswa yang sering disebut sebagai Generasi Z. Tujuan penelitian ini adalah untuk mengetahui perbedaan motivasi belajar mahasiswa yang diberikan media pembelajaran sesuai dengan karakter Generasi Z. Penelitian ini merupakan penelitian kuasi eksperimen dengan one sample pretest-posttest design. Sampel dalam penelitian ini adalah 21 mahasiswa di Jurusan Matematika, UIN Alauddin Makassar. Data hasil penelitian dikumpulkan menggunakan kuesioner dan dianalisis menggunakan uji t. Hasil penelitian menunjukkan bahwa terdapat perbedaan motivasi sebelum dan sesudah diberikan media pembelajaran sesuai dengan karakter Generasi Z (bahan ajar yang menarik, penggunaan motion graphic, sli.do, kahoot dan strategi problem solving berdasarkan permasalahan kehidupan sehari-hari). Kata Kunci: Generasi Z, Motion graphic, Sli.do, Kahoot, Problem solving
\end{abstract}

\section{The Effect of Learning Media on Learning Motivation: Overview based on Generation Z Character}

\begin{abstract}
One interesting problem is the difference in the character of students who are often referred to as Generation $\mathrm{Z}$. The purpose of this study was to determine differences in student learning motivation given learning media in accordance with Generation $Z$ characters. This research is a quasi-experimental study with one sample pretestposttest design. The sample in this study were 21 students in the Department of Mathematics, UIN Alauddin Makassar. Research data were collected using a questionnaire and analyzed using $t$ test. The results showed that there were differences in motivation before and after learning media were given according to Generation $\mathrm{Z}$ characters (interesting teaching materials, use of motion graphics, sli.do, kahoot and problem solving strategies based on problems of daily life).
\end{abstract}

Keywords: Generation Z, Motion graphic, Sli.do, Kahoot, Problem solving

How to Cite: Nawawi, M., I. (2020). Pengaruh Media Pembelajaran terhadap Motivasi Belajar: Tinjauan berdasarkan Karakter Generasi Z. Jurnal Penelitian dan Pengkajian Ilmu Pendidikan: e-Saintika, 4(2), 197210. doi:https://doi.org/10.36312/e-saintika.v4i2.216

\section{PENDAHULUAN}

Dosen sebagai tenaga pendidik sangatlah penting dalam pelaksanaan proses pembelajaran untuk mewujudkan tujuan pendidikan antara lain mengembangkan potensi mahasiswa menjadi manusia yang beriman, bertakwa kepada Tuhan Yang Maha Esa, sehat, cakap, berakhlak mulia, kreatif, mandiri dan menjadi warga negara yang demokratis serta bertanggung jawab. Dibutuhkan keahlian di bidang yang digeluti dan kemampuan untuk mengetahui potensi/bakat yang dimiliki oleh mahasiswa, bukan hanya itu, tetapi sebagai tenaga pendidik harus mempunyai 
kreativitas dalam melaksanakan proses pembelajaran. Revell dan Wainwright (2009) mengemukakan bahwa selain mahasiswa, tenaga pendidik juga harus memberikan solusi terhadap permasalahan-permasalahan yang dihadapi dalam proses pembelajaran.

Salah satu cara tenaga pendidik adalah bentuk kreativitas dengan menggunakan media pembelajaran sebagai sarana penunjang. Dengan perkembangan teknologi yang sangat pesat, saat ini banyak media pembelajaran yang bisa digunakan, akan tetapi harus didasarkan pada karakter subjek pembelajaran, yang dalam hal ini adalah mahasiswa.

Sebagai Pendidik, salah satu permasalahan yang sedang menarik adalah perbedaan karakter generasi sebagai mahasiswa (Generasi Z). Fenomena kemunculan Generasi Z menggantikan masa generasi Y yang dikenal dengan Generasi Milenial terbilang sangat cepat. Saat ini Generasi Milenial yang berada pada usia produktif antara usia 23-37 tahun. Jumlah generasi milenial mencapai sekitar 88 juta jiwa atau $33,75 \%$ dari total penduduk Indonesia. Proporsi tersebut lebih besar dari proporsi generasi sebelumnya seperti generasi $X$ yang $(25,74 \%)$ maupun generasi baby boom+veteran (11,27\%). Demikian juga dengan jumlah Generasi Z baru mencapai sekitar 29,23\% (Kementrian Pemberdayaan Perempuan dan Perlindungan Anak Statistik Gender, 2018) seperti disajikan pada Gambar 1.

\section{KOMPOSISI PENDUDUK MENURUT GENERASI TAHUN 2017}

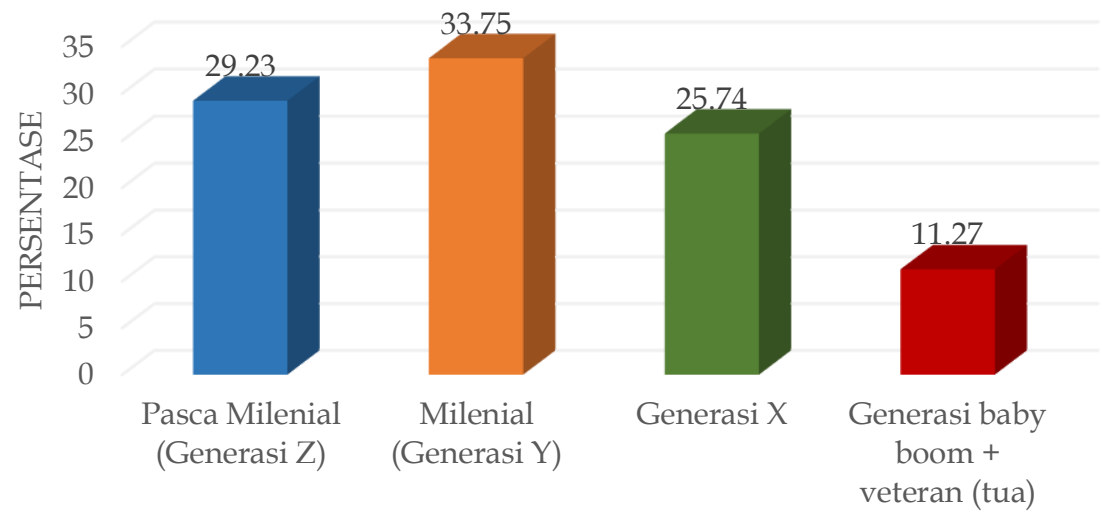

GENERASI

Gambar 1. Komposisi penduduk menurut generasi.

Secara sederhana roda perekonomian saat ini ada di tangan Generasi Milenial. Indikatornya sederhana, Generasi Milenial berada pada usia produktif dan dapat dilihat juga dari kemunculan tokoh-tokoh yang mempengaruhi dunia mulai dari pendiri Facebook Mark Zuckerberg (36 tahun), Nadiem Makarim CEO Gojek yang sekarang jadi Menteri Pendidikan (35 tahun), William Tanuwijaya CEO Tokopedia (37 tahun), Achmad Zaky CEO Bukalapak (33 tahun) dan berbagai kisah sukses Generasi Milenial lainnya.

Sedangkan Generasi Z yang lahir antara tahun 1996-2010 sedang mengenyam dunia pendidikan mulai tingkat dasar sampai perguruan tinggi dan sebagian sudah mulai masuk dunia kerja. Artinya dengan kemajuan pesat dunia teknologi seperti sekarang ini, Generasi Z diprediksi menjadi generasi terpelajar dan lebih melek jika dibandingkan dengan generasi sebelumnya karena Generasi Z adalah generasi pertama yang tumbuh di dunia internet dimana pemahaman mereka tentang akses 
ke informasi dan dunia pandangan telah dibentuk dengan cara tidak seperti generasi sebelumnya (Betz, 2019).

Generasi Z menggunakan fasilitas multimedia dan berbagai bentuk teknologi di kehidupan sehari-hari. Berbagai perangkat elektronik secara yang sering digunakan adalah smartphone, iPad, tablet, smartphone dan laptop. Hal ini berarti informasi dengan mudah didapatkan. Adapun kebutuhan pembelajaran generasi $\mathrm{Z}$ termasuk akses konten data, visualisasi grafik, kegiatan kinestetik, pemecahan masalah, kecepatan, kemudahan dalam mendapatkan informasi, integrasi multimedia interaktif, multi-tasking, tugas dan latihan pemecahan masalah alih-alih mengingat, bekerja dalam tim/kelompok kecil, keterlibatan dalam kreativitas dan kolaborasi, fleksibilitas untuk belajar sesuai dengan kebutuhan (Chun, Dudoit \& Fujihara, 2016)

Fenomena kemunculan Generasi $\mathrm{Z}$ di tengah kemajuan dunia teknologi informasi perlu disikapi dan mendapat respon khususnya oleh dunia pendidikan. Sebab konsep pendidikan yang diterapkan pada generasi millenial diprediksi tidak akan lagi cocok mengingat karakteristik Generasi Z yang berbeda dengan Generasi Milenial. Salah satunya adalah mengenai media pembelajaran yang digunakan, berdasarkan karakteristik dari generasi Z yang lahir di era perkembangan teknologi, maka pendidik sebaiknya memberikan media pembejaran yang dapat meningkatkan suasana pembelajaran yang kondusif.

Penelitian mengenai media pembelajaran Generasi Z di Indonesia sangatlah minim dan hampir tidak ada, padahal mengetahui karakter mahasiswa yang diajar sangatlah penting, terdapat beberapa penelitian sebelumnya mengenai generasi $\mathrm{Z}$ dan karakretistiknya seperti Turner (2018) yang menemukan bahwa penggunaan teknologi dan perilaku sosial sangat dibutuhkan generasi $\mathrm{Z}$ dan memberikan banyak manfaat, antara lain dapat mengakses informasi dengan cepat dan efisien, menumbuhkan keterampilan dalam pemecahan masalah sebagai sarana penyambung antara dosen dan mahasiswa, meningkatkan pengalaman belajar dan kemampuan multitasking. Similler dan Grace (2017) menyatakan terdapat empat cara generasi $\mathrm{Z}$ melakukan pembelajaran efektif di jenjang perguruan tinggi, yaitu pembelajaran berbasis video, membuat tugas individu dan kelompok, pembelajaran yang berdasarkan kehidupan sehari-hari, peluang magang. Lebih lanjut Nicholas (2018) menjelaskan media literatur generasi $\mathrm{Z}$ menggunakan literatur akses ke internet, iPod, dan iPhone sebagai kemudahan dalam mendapatkan informasi, membutuhkan lingkungan belajar yang dinamis dan kerja tim adalah salah satu hal penting.

Dalam penelitian ini, digunakan beberapa media pembelajaran yang disesuaikan dengan karakteristik Generasi Z yang berguna untuk pembelajaran yang aktif dan efektif diantaranya adalah membuat bahan ajar metode statistika yang menarik, melaksanakan kuliah metode statistika dengan pendahuluan melalui media video/motion graphics, melaksanakan pembelajaran dengan interaksi bertanya melalui aplikasi sli.do, melakukan proses problem solving melalui media ppt (ilustrasi kasus dalam kehidupan sehari-hari) dan melakukan kegiatan kuis sebagai bentuk evaluasi di akhir pembelajaran melalui aplikasi kahoot.

Motion graphic adalah teknik yang menggabungkan media visual, dengan demikian, objek tampak dinamis dan menarik. Ada dua metode dalam teknik ini, yaitu gambar yang bergerak, dan menggabungkan urutan gambar dengan kontinuitas (Amali, Zees, \& Suhada, 2020), sedangkan Slido (atau Sli.do) adalah alat interaksi konferensi. Aplikasi ini dirancang menggunakan smartphone, tablet, laptop 
dalam mengemukakan pendapat dan pilihan bagi audiens untuk mengajukan pertanyaan dari dosen. Hal ini dapat membatu mahasiswa dalam mengemukakan pendapat yang cemerlang tetapi tidak mempunyai percaya diri yang tinggi untuk mengemukakan (Compton \& Allen, 2018).

Media-media tersebut disajikan dalam rangkaian pembelajaran berbasis Problem solving yang merupakan strategi pembelajaran yang menuntut mahasiswa mencari solusi dari permasalahan-permasalahan yang diajukan oleh dosen baik secara mandiri atau secara bersama-sama. Strategi ini dapat menjadikan mahasiswa lebih aktif, terampil dan mampu menemukan solusi secara tepat dan struktur apabila dipandu tepat oleh dosen (Gurat, 2018) yang selanjutnya diakhiri dengan evaluasi pembelajaran menggunakan kahoot yang merupakan platform pembelajaran yang disajikan sebagai alat permainan yang memungkinkan gamifikasi dan integrasi smartphone di kelas maupun acara kegiatan lainnya. Dengan adanya kahoot dapat meningkatkan partisipasi mahasiswa dan hubungan antar kelompok yang berbeda (Prieto, Palma, Tobías, \& León, 2019). Penelitian ini bertujuan untuk mengetahui perbedaan motivasi sebelum dan sesudah diberikan media pembelajaran sesuai dengan karakter Generasi Z yang dilaksanakan pada mata kuliah metode statistika angkatan 2019 jurusan Matematika UIN Alauddin Makassar.

\section{METODE}

Jenis penelitian yang digunakan dalam penelitian ini yaitu kuasi eksperimental yaitu penelitian yang mempunyai tujuan mengetahui ada atau tidaknya perbedaan dari perlakuan yang diberikan kepada subjek. Kemudian membandingkan dengan subjek yang tidak diberikan perlakuan. Penelitian ini dilaksanakan pada bulan Oktober-November 2019 di Jurusan Matematika, Fakultas Sains dan Teknologi, UIN Alauddin Makassar. Adapun subjek penelitian yaitu Mahasiswa Mata Kuliah Metode Statistika Jurusan Matematika sebagai Generasi Z sebanyak 21 orang, Fakultas Sains dan Teknologi UIN Alauddin Makassar.

Intrumen pengumpulan data variabel media pembelajaran dalam penelitian ini menggunakan kuesioner/angket. Setiap pernyataan kuesioner/angket diukur menggunakan skala likert. Skala likert adalah salah satu alat psikometrik yang paling mendasar dan sering digunakan di Indonesia dalam penelitian ilmu social dan pendidikan. Skala likert yang digunakan dalam penelitian ini menggunakan 5 skala yaitu SS = Sangat Setuju, S = Setuju, R = Ragu-ragu, TS = Tidak Setuju, STS = Sangat Tidak Setuju (Joshi, Kale, Chandel, \& Pal, 2015). Pedoman penskoran respon mahasiswa disajikan pada Tabel 1.

Tabel 1. Skor jawaban angket penelitian

\begin{tabular}{|c|c|}
\hline Jawaban & Skor \\
\hline Sangat Setuju & 5 \\
\hline Setuju & 4 \\
\hline Ragu-Ragu & 3 \\
\hline Tidak Setuju & 2 \\
\hline Sangat Tidak Setuju & 1 \\
\hline
\end{tabular}

Data hasil penelitian selanjutnya dianalisis secara deskriptif dan statistik inferensial. Adapun langkah-langkah dalam statistik inferensial yang digunakan dalam penelitian ini adalah (1) uji validitas instrumen, (2) uji reliabilitas instrumen, 
(3) uji normalitas, (4) uji homogenitas, dan (5) uji hipotesis.

Adapun hipotesis statistik yang diuji dalam penelitian ini adalah

$H_{0}$ : Tidak terdapat perbedaan motivasi sebelum dan sesudah diberikan media pembelajaran sesuai dengan karakter Generasi Z yang dilaksanakan di kelas mata kuliah metode statistika angkatan 2019 jurusan Matematika UIN Alauddin Makassar; dan

$H_{1}$ : Terdapat perbedaan motivasi sebelum dan sesudah diberikan media pembelajaran sesuai dengan karakter Generasi Z yang dilaksanakan di kelas mata kuliah metode statistika angkatan 2019 jurusan Matematika UIN Alauddin Makassar.

\section{HASIL DAN PEMBAHASAN}

Berdasarkan hasil uji validitas instrumen penelitian berbentuk angket respon dengan 11 item pernyataan dinyatakan valid dan reliabel. Hasil uji validitas dan reliabilitas disajikan pada Tabel 2 dan Tabel 3.

Tabel 2. Validitas butir pernyataan angket respon mahasiswa.

\begin{tabular}{cccc}
\hline Butir & $r_{\text {hitung }}$ & $r_{\text {tabel }}$ & Keterangan \\
\hline 1 & 0,442 & 0,432 & Valid \\
2 & 0,463 & 0,432 & Valid \\
3 & 0,693 & 0,432 & Valid \\
4 & 0,807 & 0,432 & Valid \\
5 & 0,763 & 0,432 & Valid \\
6 & 0,468 & 0,432 & Valid \\
7 & 0,562 & 0,432 & Valid \\
8 & 0,480 & 0,432 & Valid \\
9 & 0,490 & 0,432 & Valid \\
10 & 0,666 & 0,432 & Valid \\
11 & 0,673 & 0,432 & Valid \\
\hline
\end{tabular}

Tabel 3. Reliabilitas instrumen

\begin{tabular}{cccc}
\hline Variabel & Cronbach's alpha & $r_{\text {tabel }}$ & Keterangan \\
\hline Media pembelajaran & 0,857 & 0,432 & Reliabel \\
\hline
\end{tabular}

Sedangkang hasil uji normalitas dan homogenitas data respon mahasiswa sebelum dan sesudah penggunaan media pembelajaran dinyatakan berdistribusi normal dan bervarian homogen seperti disajikan pada Tabel 4 dan Tabel 5.

\begin{tabular}{lccc}
\hline \multicolumn{1}{c}{ Variabel } & Sig. Shapiro-Wilk & P-Value & Normalitas \\
\hline Media pembelajaran (Sebelum) & 0,158 & 0,05 & ya \\
Media pembelajaran (Setelah) & 0,189 & 0,05 & ya \\
\hline
\end{tabular}

Tabel 5. Homogenitas data respon mahasiswa

\begin{tabular}{rccc}
\hline Variabel & Sig. Lavene & P-Value & Keterangan \\
\hline Media pembelajaran & 0,878 & 0,05 & Homogen \\
\hline
\end{tabular}


Pengujian hipotesis statistik yang diajukan dalam penelitian ini juga menunjukkan bahwa terdapat perbedaan motivasi belajar mahasiswa setelah pembelajaran menggunakan media yang bervariasi seperti disajikan pada Tabel 6.

Tabel 6. Hasil uji hipotesis

\begin{tabular}{ccc}
\hline Variabel & $t_{\text {hitung }}$ & Sig \\
\hline Media pembelajaran & 2,24 & 0,03 \\
\hline
\end{tabular}

Berdasarkan Tabel 6, didapatkan nilai t sebesar 2,24 dengan signifikansi sebesar 0,03. Berdasarkan kriteria keputusan Uji t dengan cara pertama, $\boldsymbol{t}_{\text {hitung }}(\mathbf{2}, \mathbf{2 4})>$ $\boldsymbol{t}_{\text {tabel }}(2,01)$ sedangkan cara kedua, Sig $(0,03)<0,05$ maka dapat disimpulkan bahwa Tolak $H_{0}$ atau terdapat perbedaan motivasi sebelum dan sesudah diberikan media pembelajaran sesuai dengan karakter Generasi Z yang dilaksanakan di kelas mata kuliah metode statistika angkatan 2019 jurusan Matematika UIN Alauddin Makassar.

Secara deskriptif, respon mahasiswa terkait penggunaan media pembelajaran yang bervariasi dinyatakan mendapatkan respon yang baik setelah pembelajaran seperti disajikan pada Gambar 2.

\section{Sebelum}

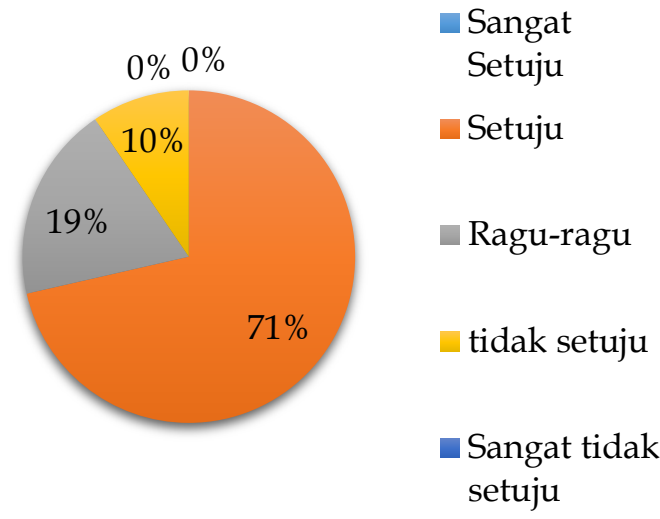

Setelah

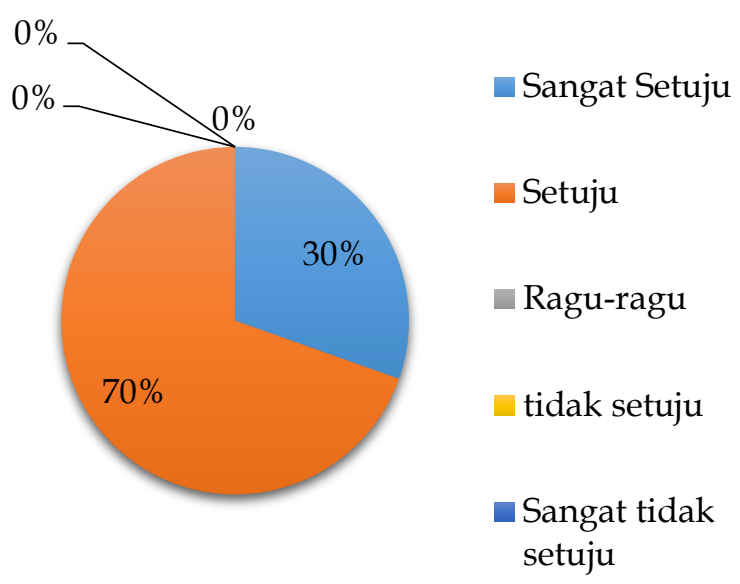

Gambar 2. Respon mahasiswa pada butir "Penggunaan media pembelajaran yang bervariasi"

Gambar 2 di atas menunjukkan sebelum dilakukan treatment, mahasiswa berpendapat media pembelajaran yang bervariasi dengan perolehan setuju $71 \%$, ragu-ragu 19\%, tidak setuju 19\% sedangkan setelah dilakukan treatment mahasiswa berpendapat media pembelajaran yang bervariasi dengan perolehan sangat setuju $30 \%$, setuju $70 \%$. Hal ini berarti mengalami peningkatan sangat setuju atau setuju dari $71 \%$ menjadi $100 \%$.

Sebelum dilakukan treatment menggunakan pembelajaran langsung dengan media pembelajaran powerpoint sedangkan setelah dilakukan treatment menggunakan pembelajaran langsung dengan media pembelajaran bahan ajar metode statistika yang menarik, melaksanakan kuliah metode statistika dengan pendahuluan melalui media video/motion graphics, melaksanakan pembelajaran dengan interaksi bertanya melalui aplikasi sli.do, melakukan proses problem solving melalui media ppt (ilustrasi kasus dalam kehidupan sehari-hari) dan melakukan kegiatan kuis sebagai bentuk evaluasi di akhir pembelajaran melalui aplikasi kahoot. 
Respon mahasiswa terkait penggunaan media pembelajaran yang bervariasi juga sejalan dengan respon mahasiswa yang menginginkan dalam pembelajaran metode statitika dapat menggunakan media pembelajaran yang bervariasi seperti disajikan pada Gambar 3.

\section{Sebelum}

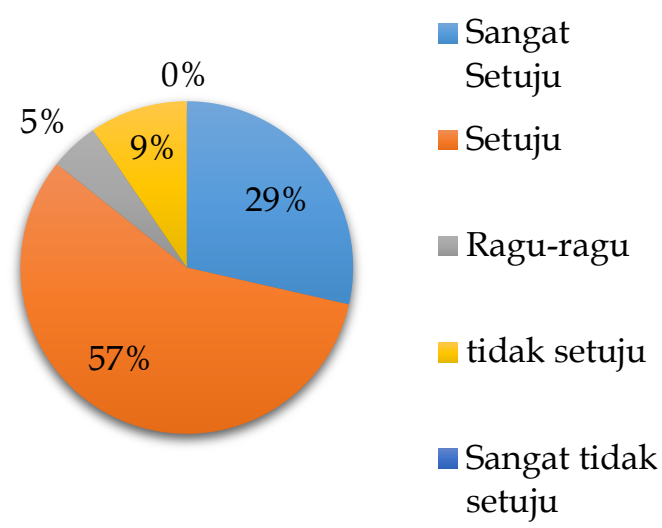

\section{Setelah}

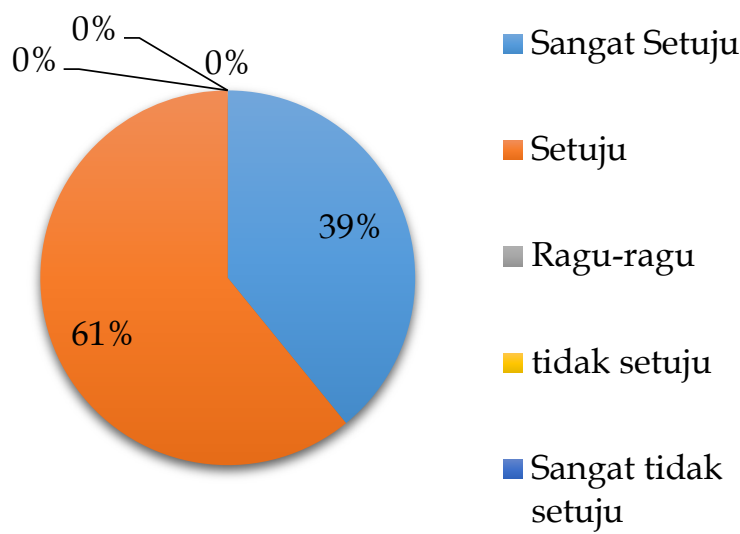

Gambar 3. Respon mahasiswa pada butir "Saya menginginkan media pembelajaran yang bervariasi"

Gambar 3 menunjukkan bahwa sebelum dilakukan treatment, mahasiswa menginginkan media pembelajaran yang bervariasi dengan perolehan sangat setuju $29 \%$ setuju $57 \%$, ragu-ragu 5\%, tidak setuju 9\% sedangkan setelah dilakukan treatment mahasiswa menginginkan media pembelajaran yang bervariasi dengan perolehan sangat setuju 39\%, setuju $61 \%$. Hal ini berarti mengalami peningkatan sangat setuju atau setuju dari $86 \%$ menjadi $100 \%$. Media pembelajaran yang bervariasi memberikan kesempatan bagi siswa untuk terlibat aktif dan meningkatkan kualitas dalam proses pembelajaran (Nadlah, 2011). Selain itu, respon mahasiswa terkait ketertarikan mengikuti pembelajaran dengan menggunakan media bervariasi juga mendapatkan respon positif seperti disajikan Gambar 4.

\section{Sebelum}

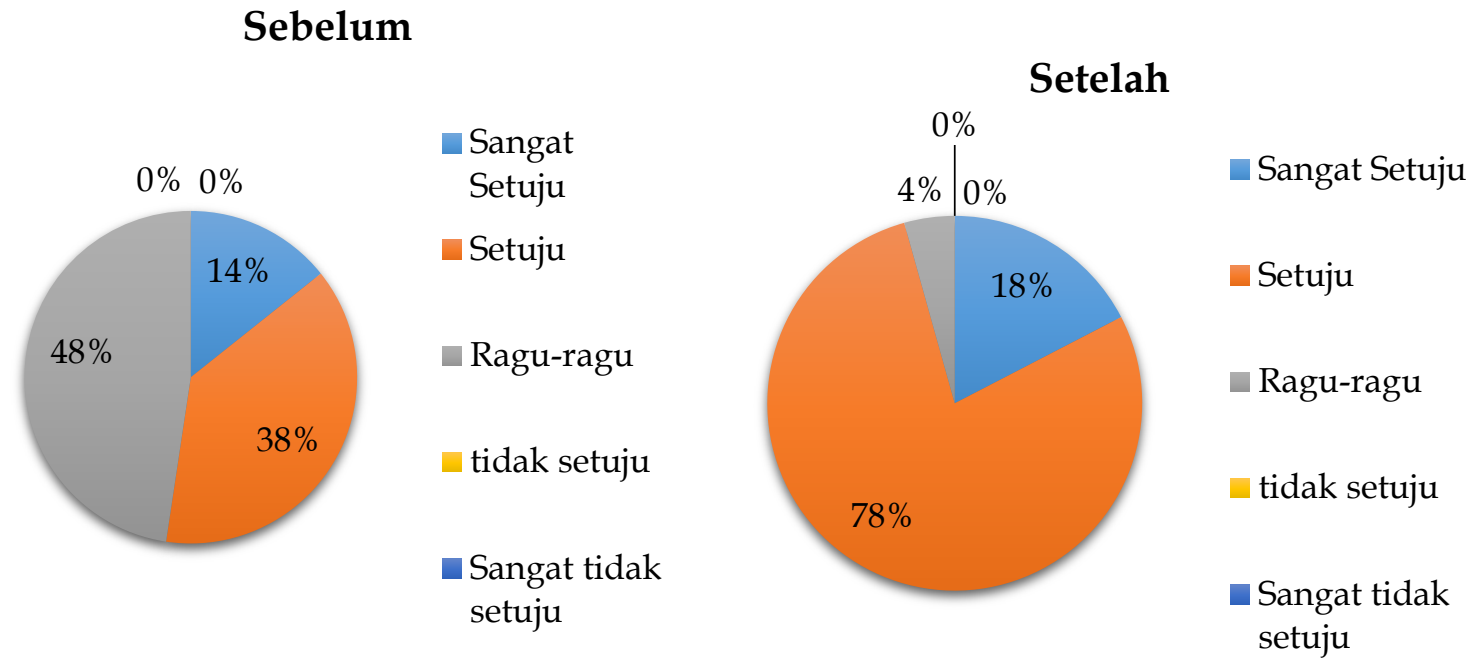

Gambar 4. Respon mahasiswa pada butir "penggunaan media pembelajaran saat ini membuat saya tertarik saat mengikuti pembelajaran di kelas"

Dari Gambar 4 di atas diketahui bahwa sebelum dilakukan treatment, mahasiswa berpendapat media pembelajaran saat ini membuat tertarik untuk 
mengikuti pembelajaran dikelas dengan perolehan sangat setuju 14\% setuju $38 \%$, ragu-ragu $48 \%$ sedangkan setelah dilakukan treatment mahasiswa berpendapat media pembelajaran saat ini membuat tertarik untuk mengikuti pembelajaran dikelas dengan perolehan sangat setuju $18 \%$, setuju $78 \%$, ragu-ragu $4 \%$. Hal ini berarti mengalami peningkatan sangat setuju atau setuju dari $52 \%$ menjadi $96 \%$. Salah satu media yang sangat diminati dan mahasiswa menjadi antusis adalah Kahoot. Hal ini menunjukkan bahwa gamifikasi pembelajaran meningkatkan minat siswa pada pelajaran, dan mendorong siswa untuk menjadi lebih ambisius untuk menang (Bicen \& Kocakoyun, 2018). Mahasiswa setelah mengikuti pembelajaran menyatakan lebih cepat mengingat materi pembelajaran (Gambar 5).

\section{Sebelum}

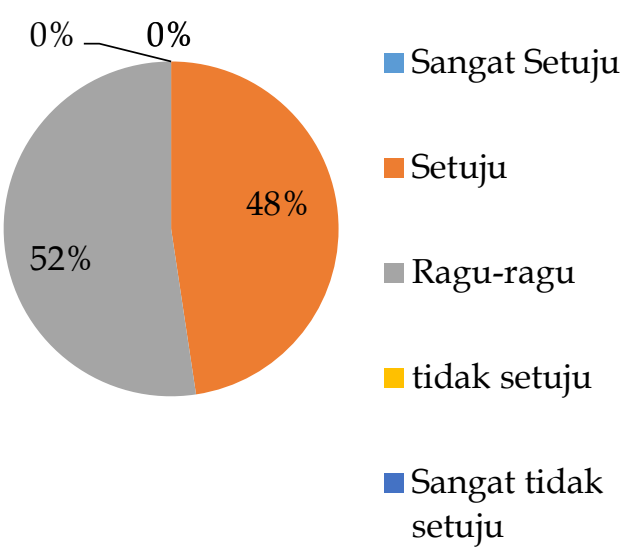

\section{Setelah}

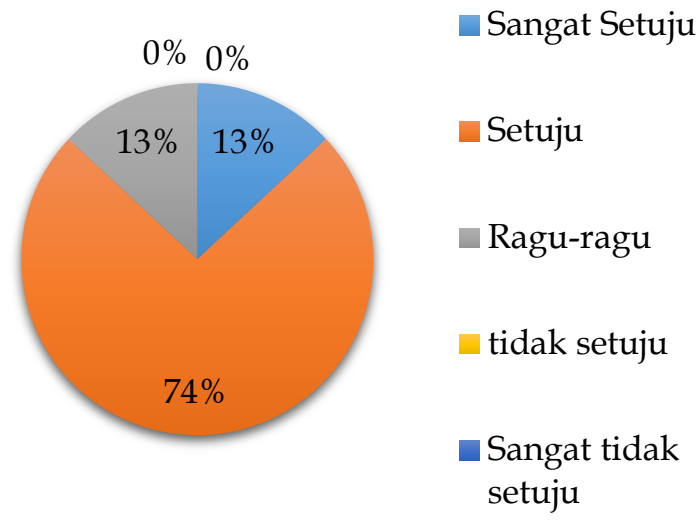

Gambar 5. Respon mahasiswa pada butir "Penggunaan media pembelajaran saat ini membuat saya cepat mengingat materi pelajaran"

Gambar 5 di atas menunjukkan sebelum dilakukan treatment, mahasiswa berpendapat penggunaan media pembelajaran saat ini membuat saya cepat mengingat materi pelajaran dengan perolehan setuju $48 \%$, ragu-ragu $52 \%$ sedangkan setelah dilakukan treatment mahasiswa berpendapat penggunaan media pembelajaran saat ini membuat saya cepat mengingat materi pelajaran dengan perolehan sangat setuju 13\%, setuju $74 \%$, ragu-ragu $13 \%$. Hal ini berarti mengalami peningkatan sangat setuju atau setuju dari $48 \%$ menjadi $87 \%$. Dalam proses problem solving melalui kehidupan sehari-hari untuk memiliki pengetahuan yang luas dasar, untuk mengurangi beban informasi dalam penyelesaian masalah, untuk meningkatkan kapasitas memori kerja mahasiswa melalui program pelatihan khusus (Solaz-Portolés\& Sanjosé-López, 2009).

Mahasiswa menyatakan bahwa memiliki semangat belajar yang lebih tinggi setelah mengikuti pembelajaran menggunakan media pembelajaran yang bervariasi. Pernyataan tersebut sesuai dengan respon mahasiswa seperti disajikan Gambar 5 berikut. 


\section{Sebelum}

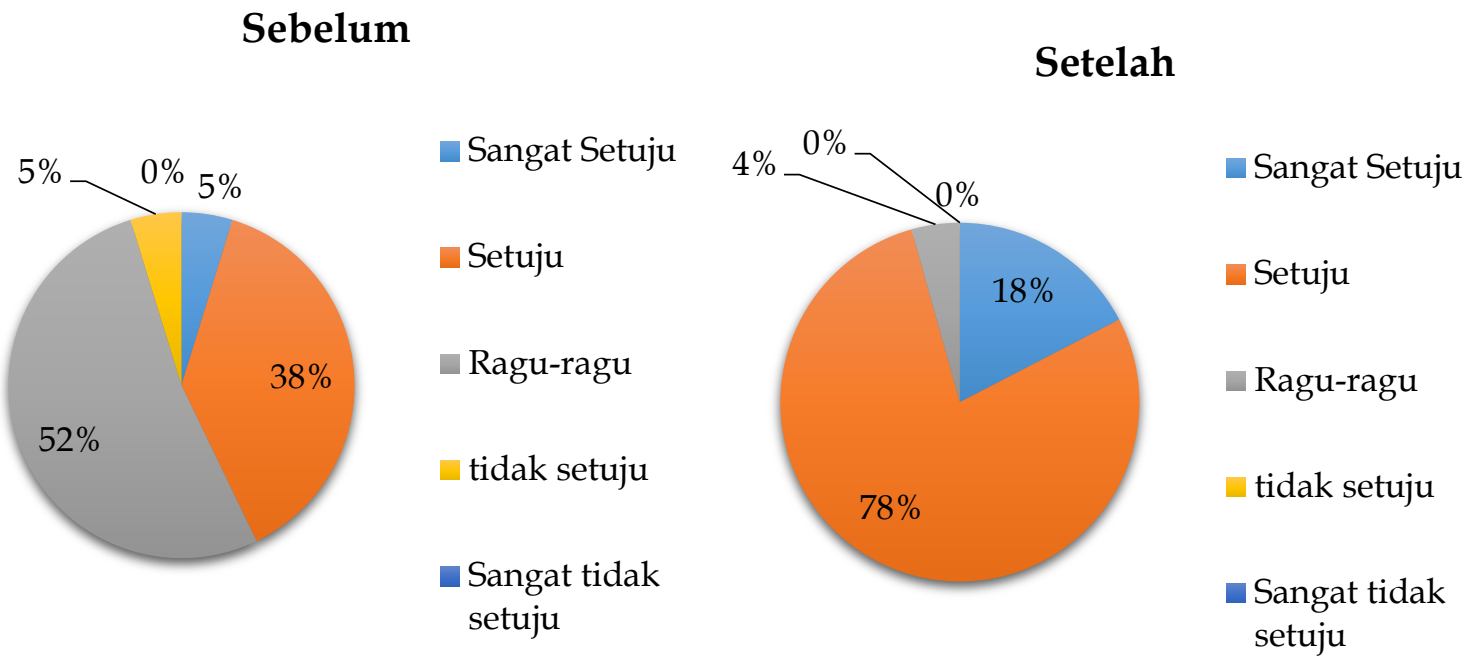

Gambar 6. Respon mahasiswa pada butir "Penggunaan media pembeljaran saat ini membuat saya semangat belajar"

Gambar 6 di atas menunjukkan sebelum dilakukan treatment, mahasiswa berpendapat penggunaan media pembeljaran saat ini membuat saya semangat belajar dengan perolehan sangat setuju 5\%, setuju 38\%, ragu-ragu 52\%, tidak setuju 5\% sedangkan setelah dilakukan treatment mahasiswa berpendapat penggunaan media pembeljaran saat ini membuat saya semangat belajar dengan perolehan sangat setuju $18 \%$, setuju $78 \%$, ragu-ragu $4 \%$. Hal ini berarti mengalami peningkatan sangat setuju atau setuju dari 90\% menjadi 96\%. Penggunaan media kahoot dapat menumbuhkan minat dan semangat dalam belajar, pengetahuan juga dapat meningkat (Mada \& Anharudin, 2019).

Sebelum

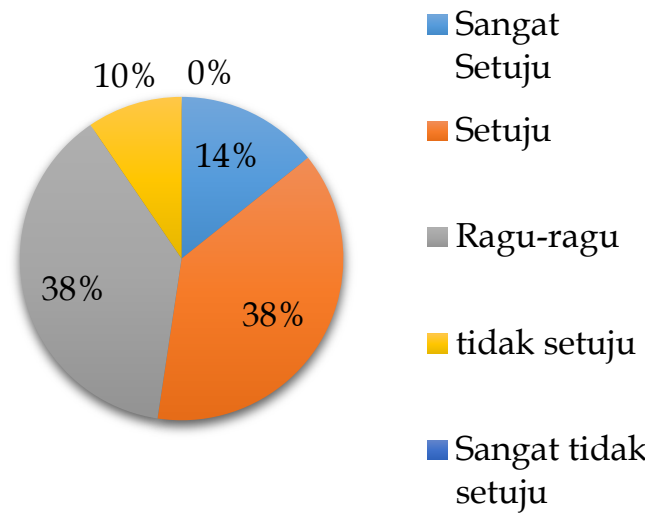

Setelah

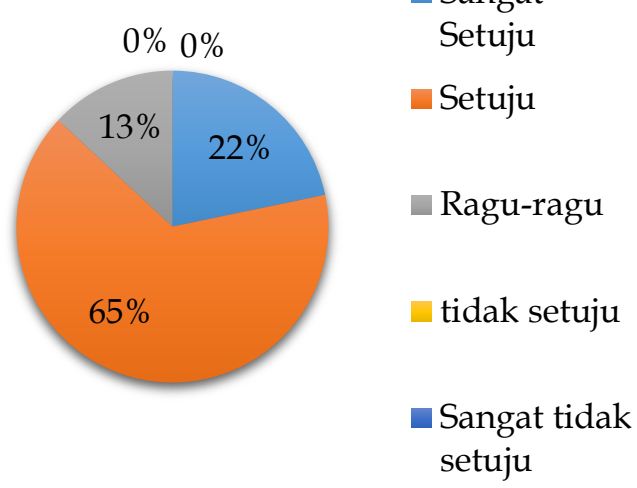

Gambar 7. Respon mahasiswa pada butir "Penggunaan media pembelajaran saat ini memudahkan saya memahami materi pelajaran"

Gambar 7 di atas menunjukkan sebelum dilakukan treatment, mahasiswa berpendapat penggunaan media pembelaajaran saat ini memudahkan saya memahami materi pelajaran dengan perolehan sangat setuju $14 \%$, setuju $38 \%$, raguragu $38 \%$, tidak setuju $10 \%$ sedangkan setelah dilakukan treatment mahasiswa berpendapat penggunaan media pembelaajaran saat ini memudahkan saya 
memahami materi pelajaran dengan perolehan sangat setuju $22 \%$, setuju $65 \%$, raguragu $13 \%$. Hal ini berarti mengalami peningkatan sangat setuju atau setuju dari 52\% menjadi 87\%. Ketika mahasiswa mengerjakan masalah, tenaga pendidik secara strategis memfasilitasi berbagi dan mengeksplorasi antara mahasiswa, membenarkan tanggapan yang telah dikemukakan di depan kelas, dan mengajukan pertanyaan untuk menyelidiki pemahaman konseptual tentang konsep. Proses memudahkan dalam pemahaman dan konseptual melalui problem solving (Selmer \& Kale, 2013).

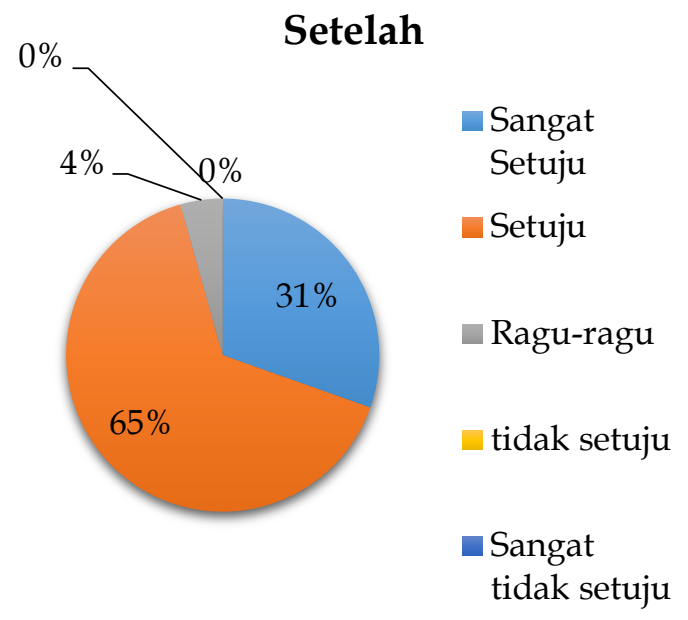

Sebelum

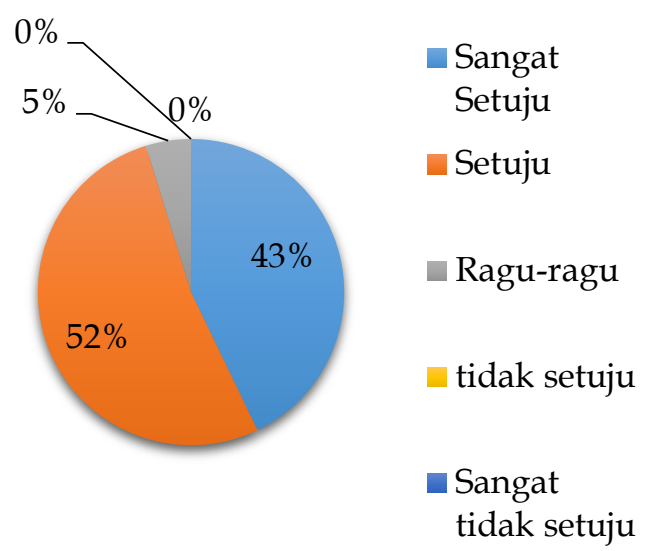

Gambar 8. Respon mahasiswa pada butir "Dosen mengajak mahasiswa berdiskusi untuk media pembelajaran yang akan digunakan"

Gambar 8 di atas menunjukkan sebelum dilakukan treatment, mahasiswa berpendapat dosen mengajak mahasiswa berdiskusi untuk media pembelajaran yang akan digunakan dengan perolehan sangat setuju $43 \%$, setuju $52 \%$, ragu-ragu $5 \%$ sedangkan setelah dilakukan treatment mahasiswa berpendapat dosen mengajak mahasiswa berdiskusi untuk media pembelajaran yang akan digunakan dengan perolehan sangat setuju 31\%, setuju 65\%, ragu-ragu 4\%. Hal ini berarti mengalami peningkatan sangat setuju atau setuju dari $95 \%$ menjadi $96 \%$. Dalam problem solving seorang tenaga pendidik memiliki tugas yaitu memfasilitasi, dengan cara memberikan waktu untuk mencari solusi dari permasalahan yang diberikan kemudian memaparkan solusi terbaik dari permasalahan tersebut (Selmer \& Kale, 2013).

Sebelum

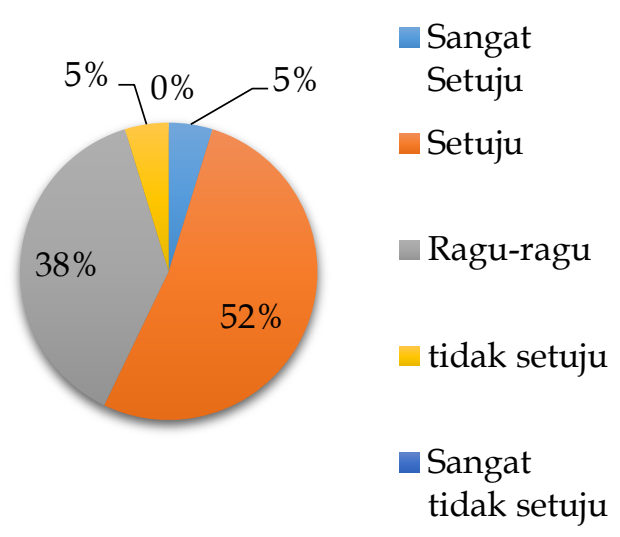

\section{Setelah}

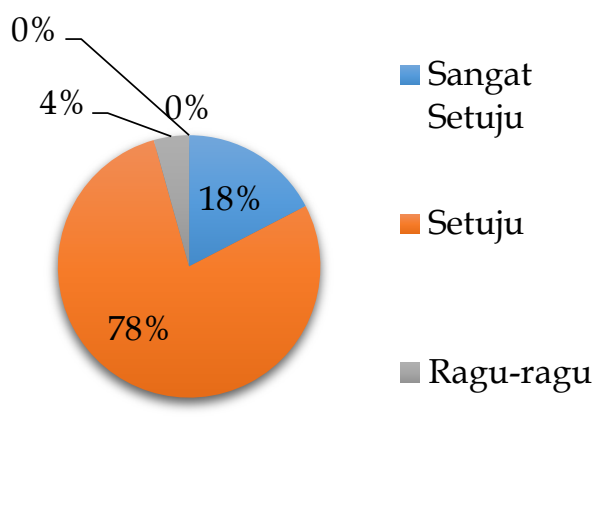

Gambar 9. Respon mahasiswa pada butir "Penggunaan media pembelajaran saat ini membuat saya aktif dalam pembelajaran" 
Gambar 9 di atas menunjukkan sebelum dilakukan treatment, mahasiswa berpendapat penggunaan media pembelajaran saat ini membuat saya aktif dalam pembelajaran dengan perolehan sangat setuju 5\%, setuju 52\%, ragu-ragu 38\%, tidak setuju 5\% sedangkan setelah dilakukan treatment mahasiswa berpendapat penggunaan media pembelajaran saat ini membuat saya aktif dalam pembelajaran dengan perolehan sangat setuju $18 \%$, setuju $78 \%$, ragu-ragu $4 \%$. Hal ini berarti mengalami peningkatan sangat setuju atau setuju dari 90\% menjadi $96 \%$. Fakta bahwa rendahnya keaktifan siswa diasumsikan karena masalah yang dijelaskan di atas, memaksa tenaga pendidik untuk memecahkan masalah. Padahal, keaktifan sangat krusial untuk kondisi yang efektif di kelas. Mengajar menggunakan aplikasi sli.do di kelas dapat meningkatkan keaktifan siswa. Itu bisa dibuktikan dengan peningkatan skor rata-rata post test di masing-masing ujian (Muthmainnah, 2019).

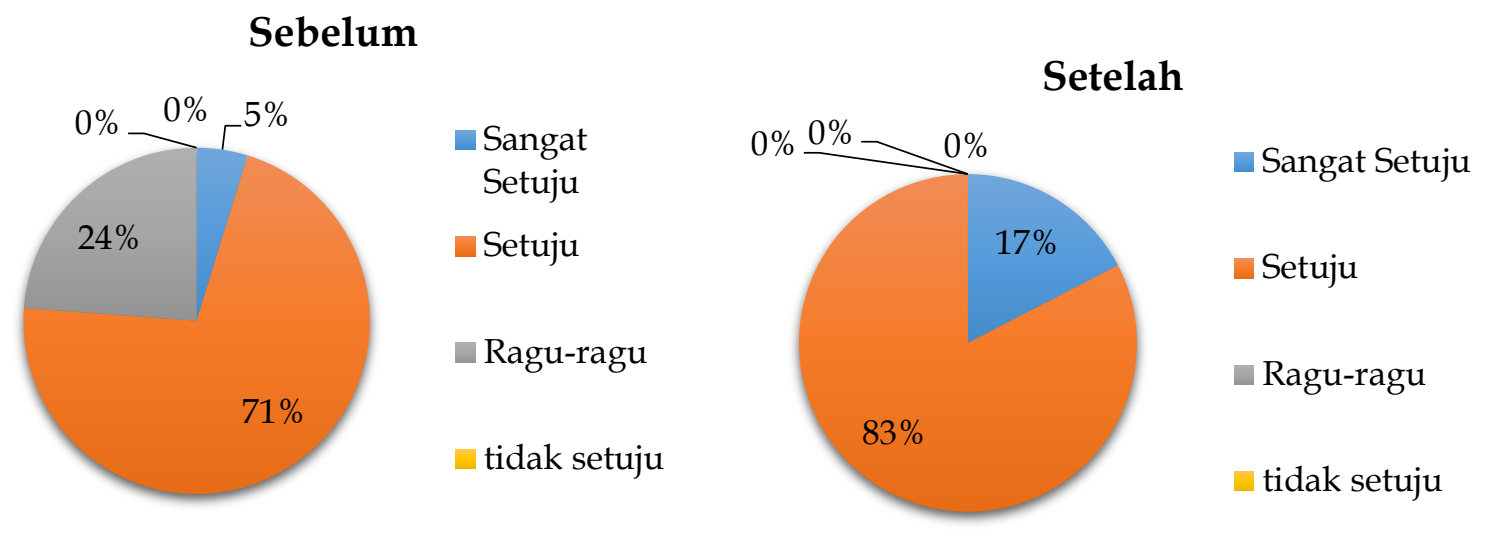

Gambar 10. Respon mahasiswa pada butir "Penggunaan media pembelajaran saat ini membuat saya termotivasi untuk giat belajar"

Gambar 10 di atas menunjukkan sebelum dilakukan treatment, mahasiswa berpendapat penggunaan media pembelajaran saat ini membuat saya termotivasi untuk giat belajar dengan perolehan sangat setuju $5 \%$, setuju $71 \%$, ragu-ragu $24 \%$ sedangkan setelah dilakukan treatment mahasiswa berpendapat penggunaan media pembelajaran saat ini membuat saya termotivasi untuk giat belajar dengan perolehan sangat setuju $18 \%$, setuju $83 \%$, ragu-ragu $4 \%$. Hal ini berarti mengalami peningkatan sangat setuju atau setuju dari 95\% menjadi 100\%. Dalam menggunakan media pembelajaran dengan memanfaatkan teknologi di dalam kelas harus disertai dengan perencanaan yang baik sehingga pembelajaran akan bermakna dan partisipasi kelas akan muncul untuk membangun motivasi dan hasil belajar mahasiswa (Gurat, 2018).

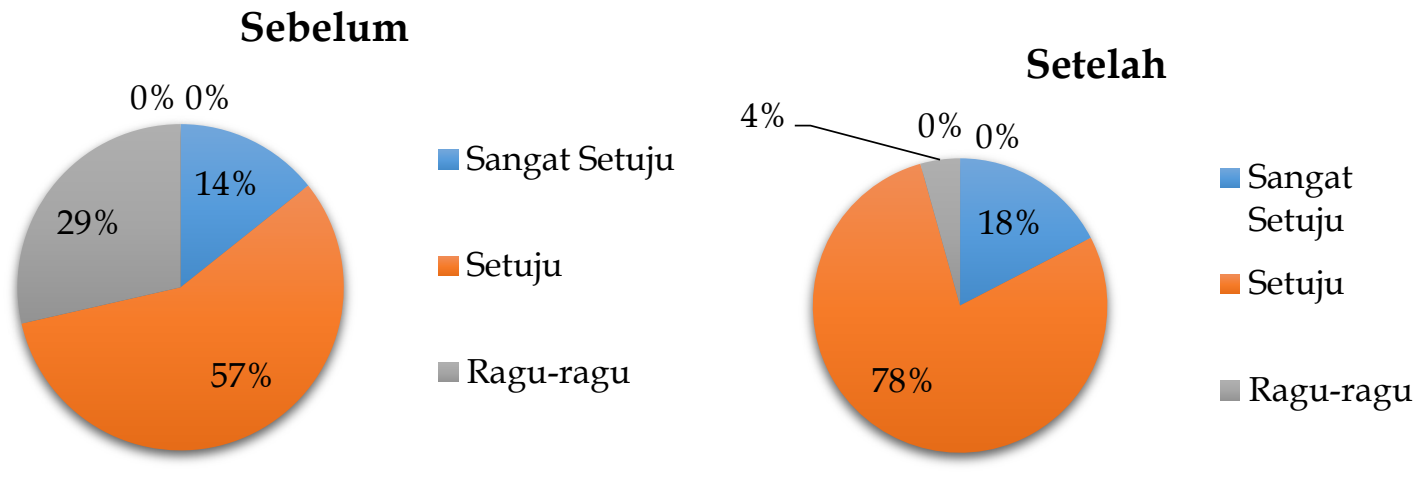

Gambar 11. Respon mahasiswa pada butir "Penggunaan media pembelajaran saat ini mendukung kegiatan belajar saya" 
Gambar 11 di atas menunjukkan sebelum dilakukan treatment, mahasiswa berpendapat penggunaan media pembelajaran saat ini mendukung kegiatan belajar dengan perolehan sangat setuju 14\%, setuju 57\%, ragu-ragu 29\% sedangkan setelah dilakukan treatment mahasiswa berpendapat penggunaan media pembelajaran saat ini mendukung kegiatan belajar dengan perolehan sangat setuju $18 \%$, setuju $78 \%$, ragu-ragu $4 \%$. Hal ini berarti mengalami peningkatan sangat setuju atau setuju dari $71 \%$ menjadi $96 \%$. Meningkatkan partisipasi kelas dengan mahasiswa yang kurang aktif, memperkuat konsep-konsep, mengkonsolidasikan pembelajaran, memberikan umpan balik langsung, meningkatkan motivasi dan kepercayaan diri, dan meningkatkan pemahaman bias dengan menggunakan sli.do (Shetty\& Ghanat, 2020).

\section{Setelah}

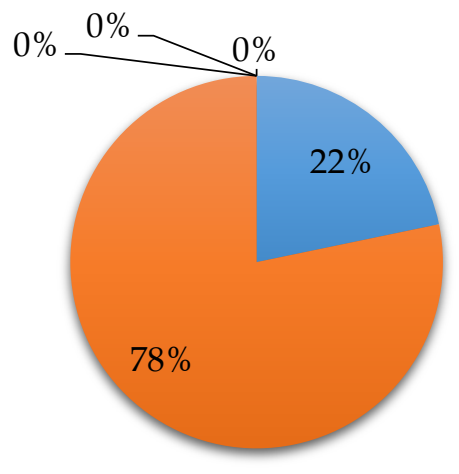

Sangat Setuju
Setuju
Ragu-ragu
tidak setuju
Sangat tidak
setuju

Sebelum

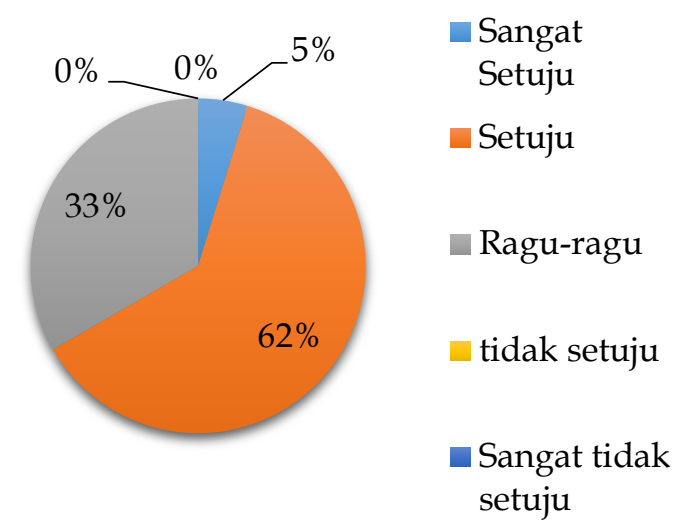

Gambar 12. Respon mahasiswa pada butir "Penggunaan media pembelajaran saat ini membuat proses belajar mengajar menyenangkan"

Gambar 12 di atas menunjukkan sebelum dilakukan treatment, mahasiswa berpendapat penggunaan media pembelajaran saat ini membuat proses belajar mengajar menyenangkan dengan perolehan sangat setuju $5 \%$, setuju $62 \%$, ragu-ragu $35 \%$ sedangkan setelah dilakukan treatment mahasiswa berpendapat penggunaan media pembelajaran saat ini membuat proses belajar mengajar menyenangkan dengan perolehan sangat setuju 22\%, setuju $78 \%$. Hal ini berarti mengalami peningkatan sangat setuju atau setuju dari 67 menjadi 100\%. Dunia grafis gerak menawarkan beragam alat untuk menarik perhatian, meningkatkan retensi dan motivasi pada siswa. Animasi dan kartun menarik orang-orang dari segala usia. Salah satunya adalah motion graphics yang memiliki kekuatan untuk menarik perhatian seseorang berjam-jam bersama tanpa membuat bosan. (Kumar, M., \& Jamil, M, 2016)

\section{KESIMPULAN}

Berdasarkan hasil penelitian, dapat disimpulkan bahwa terdapat perbedaan motivasi sebelum dan sesudah diberikan media pembelajaran sesuai dengan karakter Generasi Z yang dilaksanakan di kelas mata kuliah metode statistika angkatan 2019 Jurusan Matematika UIN Alauddin Makassar, di samping itu, minat belajar mahasisiwa (Generasi Z) dinyatakan lebih tinggi setelah pembelajaran menggunakan media pembelajaran yang variatif diantaranya video/motion graphics, sli.do, ilustrasi berbasis problem solving dan kahoot. 


\section{SARAN}

Beberapa saran yang dapat diajukan setelah melakukan penelitian ini diantaranya (1) penelitian selanjutnya perlu mengembangkan media pembelajaran yang dapat diintegrasikan pada model pembelajaran yang lebih kompleks dan ruang lingkup sampel yang lebih besar lagi, (2) menyikapi wabah pandemik Covid-19 yang dihadapi saat ini, perlu diteliti lebih lanjut apakah Mahasiswa (Generasi Z) sudah siap dengan perkuliahan daring, dan (3) perlu penyelidikan lebih lanjut mengenai keterkaitan antara karakteristik Generasi Z dengan faktor-faktor penghambat kuliah daring seperti lokasi terpencil, sinyal yang kurang memadai dan sebagainya dengan menggunakan sampel yang besar.

\section{DAFTAR PUSTAKA}

Allen, R. P., Kosinski, M., Hill-Zabala, C. E., \& Calloway, M. O. (2009). Psychometric evaluation and tests of validity of the Medical Outcomes Study 12-item Sleep Scale (MOS sleep). Sleep Medicine, 10(5), 531-539. https://doi.org/10.1016/j.sleep.2008.06.003

Amali, L. N., Zees, N., \& Suhada, S. (2020). MOTION GRAPHIC ANIMATION VIDEO AS ALTERNATIVE LEARNING MEDIA. Jambura Journal of Informatics, 2(1). https://doi.org/10.37905/jji.v2i1.4640

Betz, C. L. (2019, January 1). Generations X, Y, and Z. Journal of Pediatric Nursing. W.B. Saunders. https:// doi.org/10.1016/j.pedn.2018.12.013

Bicen, H., \& Kocakoyun, S. (2018). Perceptions of students for gamification approach: Kahoot as a case study. International Journal of Emerging Technologies in Learning, 13(2), 72-93. https://doi.org/10.3991/ijet.v13i02.7467

Compton, M., \& Allen, J. (2018). Student Response Systems: a rationale for their use and a comparison of some cloud-based tools. Compass: Journal of Learning and Teaching (Vol. 11).

Chun C, Dudoit K., Fujihara S. (2016).Teaching Generation Z at the University of Hawaii

Gamification of Kahoot! Boosts Students' Motivation in ESL Classroom Rosmawati binti Mohd Daud. (n.d.). 746-752.

Gurat, M. G. (2018). Mathematical problem-solving strategies among student teachers. Journal on Efficiency and Responsibility in Education and Science, 11(3), 53-64. https://doi.org/10.7160/eriesj.2018.110302

Heale, R., \& Twycross, A. (2015). Validity and reliability in quantitative studies. Evidence-Based Nursing. BMJ Publishing Group. https://doi.org/10.1136/eb2015-102129

Kim, T. K. (2015). T test as a parametric statistic. Korean Journal of Anesthesiology, 68(6), 540-546. https://doi.org/10.4097/kjae.2015.68.6.540

Joshi, A., Kale, S., Chandel, S., \& Pal, D. (2015). Likert Scale: Explored and Explained. British Journal of Applied Science $\mathcal{E}$ Technology, 7(4), 396-403. https://doi.org/10.9734/bjast/2015/14975

Mada, R. D., \& Anharudin, A. (2019). How Online Learning Evaluation (Kahoot) Affecting Students' Achievement and Motivation (Case Study on it Students). International Journal for Educational and Vocational Studies, 1(5), 422-427. https://doi.org/10.29103/ijevs.v1i5.1494

Mohd Razali, N., \& Bee Wah, Y. (2011). Power comparisons of Shapiro-Wilk, KolmogorovSmirnov, Lilliefors and Anderson-Darling tests. Journal of Statistical Modeling and Analytics (Vol. 2). 
Muthmainnah, N. (2019). An Effort to Improve Students' Activeness at Structure Class Using Slido App. JEES (Journal of English Educators Society), 4(1), 1. https://doi.org/10.21070/jees.v4i1.1868

Nadlah, Izzun. (2011). Penerapan Media Pembelajaran Bervariasi Dapat Meningkatkan Kualitas Pembelajaran Materi Saling Ketergantungan Dalam Ekosistem Pada Siswakelas Viid Smpn 40 Semarang. Jurnal Penelitian Pendidikan, 28(1). https://doi.org/10.15294/jpp.v28i1.5624

Nicholas, A. (2018). Digital Commons @ Salve Regina Preferred Learning Methods of the Millennial Generation. Retrieved from http://digitalcommons.salve.edu/fac_staff_pub\%0Ahttp://digitalcommons.sa lve.edu/fac_staff_pub/18

Kementrian Pemberdayaan Perempuan dan Perlindungan Anak Statistik Gender (2018). Tematik: Profil Generasi Milenial Indonesia STATISTIK GENDER TEMATIK: PROFIL GENERASI MILENIAL INDONESIA. Jakarta

Kumar, M., \& Jamil, M. (2016). Enhanced Learning Using Motion Graphics in Higher Education. ICERI2016 Proceedings, 1(May), 2647-2651. https://doi.org/10.21125/iceri.2016.0157

Prieto, M. C., Palma, L. O., Tobías, P. J. B., \& León, F. J. M. (2019). Student assessment of the use of kahoot in the learning process of science and mathematics. Education Sciences, 9(1). https:// doi.org/10.3390/educsci9010055

Revell, A., \& Wainwright, E. (2009). What makes lectures "unmissable"? Insights into teaching excellence and active learning. Journal of Geography in Higher Education, 33(2), 209-223. https:/ / doi.org/10.1080/03098260802276771

Seemiller, C., \& Grace, M. (2017). Generation Z: Educating and Engaging the Next Generation of Students. About Campus, 22(3), 21-26. https://doi.org/10.1002/abc.21293

Shetty, N. H., \& Ghanat, S. (2020). Slido as a student response system in engineering education. ASEE Southeastern Section Meeting.

Selmer, S., \& Kale, U. (2013). Teaching mathematics through problem solving. Innovación Educativa, 13(62), 45-59.

Solaz-Portolés, J. J., \& Sanjosé-López, V. (2009). Working memory in science problem solving: A review of research. Revista Mexicana de Psicologia, 26(1), 79-90.

Turner, A., \& Turner, A. (2018). Generation Z: Technology and Social Interest Generation Z: Technology and Social Interest, 71(2), 103-113.

Shukor, M., Y., \& Shukor, A, M., Y. (2016). Bartlett and the Levene's Tests of Homoscedasticity of the Modified Gompertz Model Used in Fitting of Burkholderia sp. strain Neni-11 Growth on Acrylamide. BSTR (Vol. 4). Retrieved from http://journal.hibiscuspublisher.com/index.php/BSTR 